\title{
The Role of Kaizen in Participation in the Global Value Chain: The Case of the Mexican Automotive Industry
}

\author{
Keiji Katai
}

\section{INTRODUCTION}

The Global Value Chain (GVC) is providing new opportunities for developing countries to promote their industrialization. Taglioni and Winkler (2016) describe a value chain as "the sequence of productive (valueadded) activities that capital and labor (or firms and workers) perform to bring a good or service from its conception to end use and beyond." From a business organization perspective the GVC can be described as a value chain that goes beyond country borders. However, rather than having to develop the whole chain themselves and compete in the consumer market with multi-national enterprises (MNEs), developing countries can now participate in those segments of the GVC where they may have a comparative advantage.

The GVC provides several benefits to firms in developing countries, such as access to larger markets, access to quality inputs, and access to knowledge. Benefits at the company level can also have a positive impact

K. Katai $(\bowtie)$

Private Sector Development Group, Industrial Development and Public Policy

Department, Japan International Cooperation Agency, Tokyo, Japan

e-mail: Katai.Keiji@jica.go.jp

(C) The Author(s) 2020

A. Hosono et al. (eds.), Workers, Managers, Productivity, https://doi.org/10.1007/978-981-15-0364-1_8 
at the country level. Kummritz (2016) shows that an increase in GVC participation causes a rise in domestic value added and in productivity. The issue then is: how can domestic firms join the GVC and under what kind of policy?

Taglioni and Winkler (2016) present a strategic framework for lower and middle-income countries (LMICs) that will maximize their gains from participation. Acknowledging the wide variety of issues identified, this chapter focuses on the capabilities of firms, especially production management capabilities, and analyzes whether Kaizen, a production management system developed in Japan for improving the quality and productivity of manufacturing, can assist domestic firms participation in the GVC.

A leading company in GVC requires a variety of suppliers to produce final goods, and it is important that all deliver inputs/parts of the required quality and quantity at competitive prices without any failures. If one company does not supply the required parts and if it is difficult to otherwise source them, the leading company might need to stop sales of final goods. Considering the above, the reliability of firms backed by effective production management systems is a critical factor in the GVC.

This chapter reports on the Mexican automotive industry. The performance of 17 domestic firms that received training in Kaizen is analyzed. Mexico has attracted major car makers and their direct suppliers (Tier-1) that use the country as a strategic base for export to the US market. In 2016, Mexico produced 3,465,615 cars and was ranked number seven in the world. Also, major global Tier-1 firms are located in Mexico and provide opportunities for domestic firms to participate in the automotive GVC, if they meet the criteria set by the buyers (Tier-1s).

Taglioni and Winkler (2016) provide policy options for GVC participation and point out the importance of the absorptive capacity of domestic firms in relation to this. However, to the best of the author's knowledge, no study has explained changes in position in the GVC in relation to the capabilities of firms, especially their production management capabilities.

The structure of this chapter is as follows: Sect. 2 presents a review of the literature on GVC participation and the effect of foreign direct investment (FDI) on productivity improvement. Section 3 provides an overview of the automotive industry and a comparison with Thailand and Indonesia, other major developing countries engaged in automotive production. Section 4 provides the hypothesis, and Sect. 5 explains the data from the 
study. Analyses of these data are undertaken in Sect. 6, and policy implications and conclusions are presented in Sect. 7.

\section{Literature REVIEW}

\subsection{How to Participate in the GVC?}

The goal of this study was to promote the participation of domestic firms in the GVC. Kummritz et al. (2017) show that favorable infrastructure, connectivity, openness of investment policy, business climate and institutions, financial and labor markets, education and skills, innovation and product standards, labor standards, social standards, and environmental standards can magnify the gains from GVC for domestic added.

Taglioni and Winkler (2016) present a strategic policy framework for LMICs to maximize their gains from the GVC. They suggest attracting FDI by providing an excellent business environment with international connectivity, guaranteeing investor protection, and so on. Once FDI is attracted, LMICs can promote participation in the GVC by backward and forward linkages, strengthening absorptive capacity, and creating an excellent workforce.

\subsection{Value Chain Disaggregation and the Automotive Value Chain}

Value addition and value chain disaggregation are widely used in analyzing GVCs. Mudambi (2008) shows this in the case of the iPhone (Fig. 8.1). Both ends of the value chain show high-value addition and the "smile curve." That paper used the Japan International Cooperation Agency (JICA) framework (JICA forthcoming) to analyze the automotive value chain in the Philippines (Fig. 8.2). Currently, this industry is going through a drastic transformation to cope with ride sharing, automated driving technology, electric vehicles, and so on. However, its hierarchical characteristics are still strong. The main value chain is the automaker original equipment manufacturer (OEM) from product planning to aftersales and service. The value chain of the Tier-1 (system/module parts producers) is closely related to OEM and the value chain of the Tier- 2 is closely related to Tier- 1 .

We depict the supply chain for automobile production by connecting the midstream of these three layers (Fig. 8.2). The focus of this chapter is 


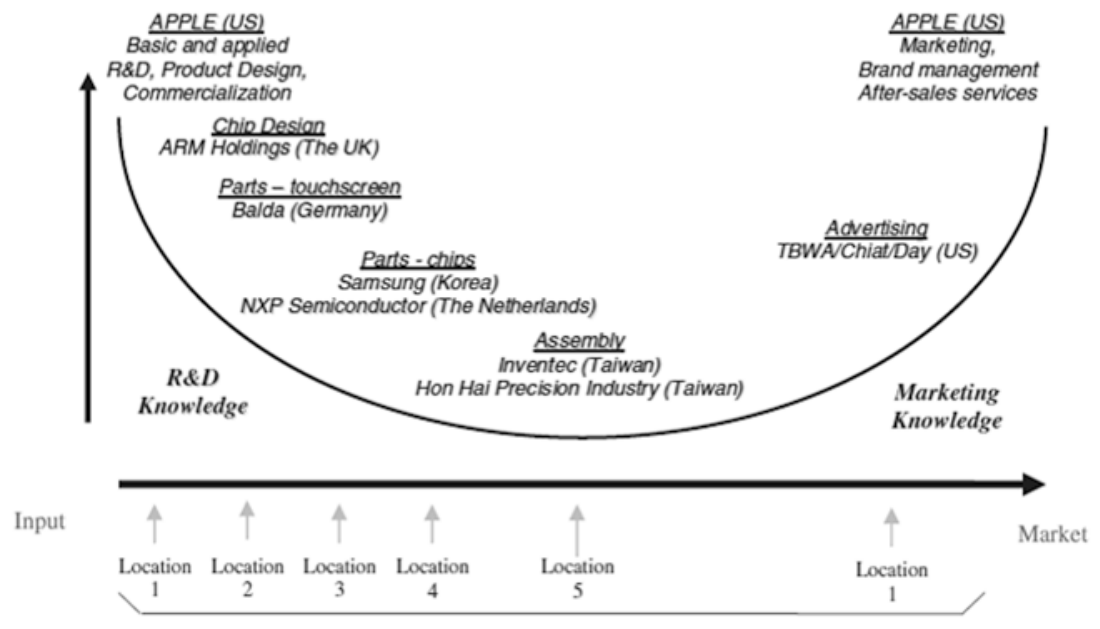

VALUE CHAIN DISAGGREGATION

Fig. 8.1 Value creation for the iPhone. (Source: Mudambi 2008)

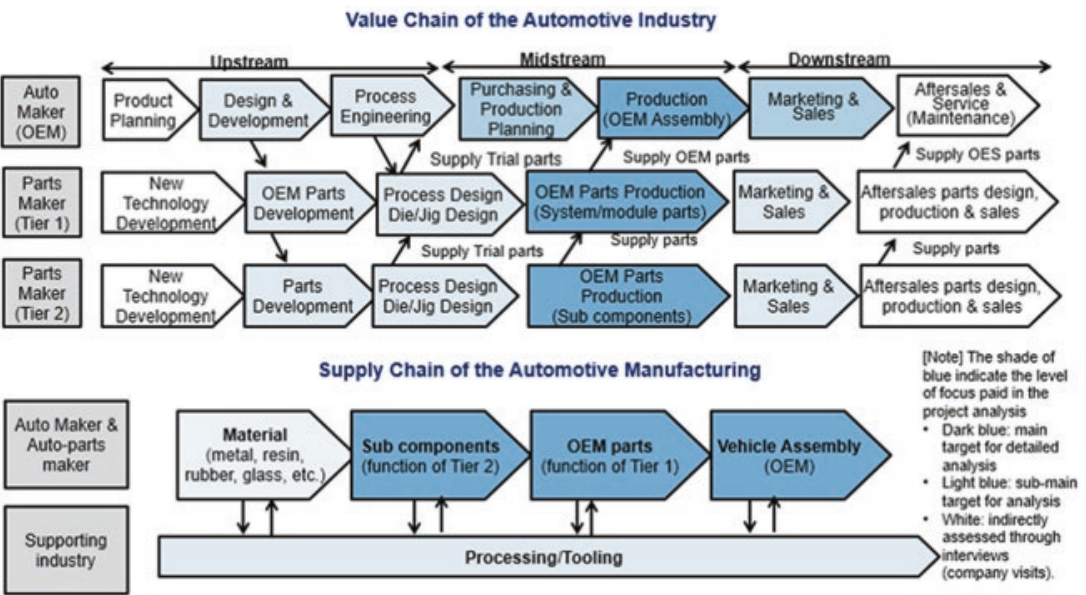

Fig. 8.2 Value chain and supply chain of the automotive industry. (Source: JICA forthcoming) 
on Tier-2, but it is necessary to analyze the Tier 2 /Tier 1 relationship as they sometimes collaborate in developing new parts.

\subsection{GVC Stages in the Automotive Industry and the Individual Firm's Position}

Even among parts makers (Tier-2), there are differences in buyer relationships. Cirera and Maloney (2017) divide the firms in the GVC from the viewpoint of capability and describe the stages of engagement as (1) the proto-connecting stage, (2) the connected stage, (3) the upgrading stage, and (4) the mature stage. They show that their characteristics are as follows: (1) at this stage firms have a minimum scale of transactions, but participation in the GVC is yet to be achieved; (2) the connected stage is an initial stage of GVC participation where the relationship is unstable and is affected by the market, but firms have basic capabilities in production and management, and can leverage these competencies to meet client demand; (3) at the upgrading stage, firms have high standards of quality and delivery and a deep relationship with other players in the chain; and (4) at the mature stage, firms have a direct relationship with the lead firm and can collaboratively conduct innovative activities.

Considering these definitions, this chapter defines the stages as follows: Stage 1 is the audit or non-supplier stage where buyers implement audits in terms of production management systems; Stage 2 is a back-up/periodic supplier; Stage 3 is a regular supplier; Stage 4 is a major supplier; Stage 5 is a partner supplier; and Stage 6 is a global partner supplier. Stages 3-5 are a breakdown of the upgrading stage as shown in Fig. 8.3.

At Stage 1, buyers use documentation, factory visits, quotations, and sample production, to examine the capacity of the potential supplier. At Stage 2, buyers order relatively small amounts of product to check whether they can use the supplier. Buyers order from these suppliers if demand increases or if there is a problem with existing suppliers. At Stage 3, buyers use several regular suppliers to diversify risk. If a supplier creates serious problems in quality or delivery, they can be downgraded to a back-up supplier. At Stage 4, the supplier has the full trust of the buyer. If the buyer has a new project, these suppliers will be the first to be asked to provide a quote. At Stage 5, the buyer develops new products in collaboration with a supplier. At Stage 6, the supplier will supply and develop products not only to domestic buyers but also to global buyers. 
(4) Mature Stage:

Direct relationship with lead firm and can conduct innovative activities

(3) Upgrading Stage:

High Standard of quality and delivery as well as relationship with other players in the chain

(2) Connected Stage :

Unstable relationship.

Firms have basic capabilities.

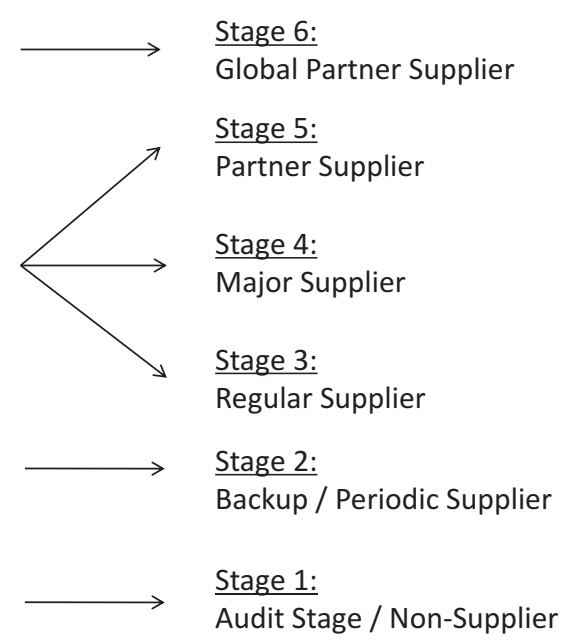

(1) Proto Connecting Stage:

Minimum scale of Transaction

Actual Participation is yet to be achieved

Audit Stage / Non-Supplier

Fig. 8.3 The concept of GVC stages. (Source: Author)

This chapter looks at whether the introduction of the Kaizen production management system can have positive impact on firms' position in the Mexican automotive GVC using these analytical stages.

\subsection{The Driving Force for Improving Positioning in the GVC: Evaluation Based on QCD}

For Tier-2 companies to move position in the GVC, they need to satisfy their clients (Tier-1s), and in the automotive sector suppliers are selected based on quality, cost, and delivery (QCD). Individual car makers or Tier-1 companies have their own evaluation criteria of new suppliers covering many items. Recently, sustainability has been emphasized in purchasing policy, but QCD is always included. Renault-Nissan uses the evaluation criteria of QCDDM (Quality, Cost, Delivery, Development, and Management). ${ }^{1}$ Honda uses QCDD (Quality, Cost, Delivery, and Development), ${ }^{2}$ and while Toyota does not mention QCD, it requires quality items at a low price and in a timely manner, which is equal to 
QCD. ${ }^{3}$ It is thus critical for Tier-2 firms to improve Tier-1 company evaluations from the viewpoint of QCD.

\subsection{Productivity Improvement, Kaizen, and Firm Capabilities}

How can Tier-2 companies improve their capabilities related to QCD? They can improve capacity either through obtaining additional internal resources or through using external resources such as backward/forward linkages with FDI and direct technical support. The concept of productivity spillover from FDI has been widely explored in earlier studies of the causal relationship between FDI and productivity improvement in forward/backward linkages. However, these produced mixed results (Görg and Greenaway 2004). While a statistically significant spillover effect on forward linkages was not observed, empirical studies have shown a causal relationship in backward linkages (see Gorodnichenko et al. 2014; Blalock and Gertler 2008; Javorick 2004).

Guzman-Anaya (2013) analyzed inter-industry productivity spillovers from Japanese and US FDI in the Mexican manufacturing sector. Their study showed that Japanese FDI increases productivity in backward-linked industries but the productivity gains accrue to foreign rather than domestic suppliers. This study targets the automotive industry in Mexico and it is possible that, in this sector, we might see positive spillover effects on domestic industries. However, productivity spillovers from FDI to domestic industry do not always happen. Cusolito et al. (2016) note that the impact of local MNEs on SMEs and other firms in low-income countries is difficult to predict. According to them it is important to look at the quality and standards that are emphasized by MNEs when upgrading domestic firms and they suggest providing direct technical assistance to firms, given that demand effects alone have a limited impact on spillover and support from MNEs tends to cover more general matters.

One possible way to implement direct technical assistance is to introduce Kaizen. As described in the introductory chapter, Kaizen is an inclusive and participatory approach to the continuous improvement of quality and productivity, resting on its distinctive philosophy and tools/methods, and is the base of management systems, including Total Quality Management (TQM) and Toyota Production System (TPS), developed in Japan and adapted to other countries. The virtue of Kaizen is its characteristic of self-sustainability. Once a company acquires capacity to implement Kaizen, it can continue to improve productivity and quality without 
relying on outside experts and it can enhance its absorptive capacity to learn from FDI.

\section{The Mexican Automotive Industry}

Since Mexico concluded the North American Free Trade Agreement (NAFTA) in 1994, it has developed the automotive industry as a base for exports to the United States. In 2016, the country exported 2,768,000 cars, ranking number three in the world. Mexico is thus a major hub for car manufacturing. However, the major players in the industry are FDI car makers and suppliers, and the presence of domestic firms in the industry is low. Also, the aggregate size of Tier- 2 and Tier- 3 parts makers in comparison with Tier-1 parts makers is much smaller than that in Thailand. Table 8.1 shows that the ratio of Tier- 2 and Tier- 3 firms to Tier- 1 firms in Thailand is more than 4 times that of Mexico. Also, the local procurement ratio by Japanese car manufacturers and suppliers is 34.6 percent and this is considerably lower than that in Indonesia (43.3 percent) and Thailand (63.1 percent) (JETRO 2018).

In 2017, 92 firms of the top-100 global Tier-1s were in Mexico. Global players increased investment recently and such trend can be seen in the changes in the countries' trade specialization index. This index is derived as (Export - Import)/(Export + Import) and it shows the dependence on imports of individual products. If a country depends on products from abroad, the index becomes negative. If the country expands local capacity reducing dependence on imports, the index comes closer to zero and when it expands further and exports more than it imports, the number becomes positive. Table 8.2 shows that the auto parts trade specialization index in Mexico has improved recently and some parts have turned positive, compared with Indonesia where most parts are still negative. At the

Table 8.1 The structure of the automotive industry

\begin{tabular}{|c|c|c|c|c|}
\hline & & Indonesia & Thailand & Mexico \\
\hline (a) & Production of vehicles in $2016(000)$ & 1177 & 1944 & 3597 \\
\hline (b) & Number of Tier-1 firms & 550 & 635 & 383 \\
\hline (c) & Number of Tier- 2 and Tier- 3 firms & 1000 & 1700 & 233 \\
\hline (d) & Tier-2 and Tier-3 ratio $(=(\mathrm{c}) /(\mathrm{b}))$ & 1.8 & 2.7 & 0.6 \\
\hline
\end{tabular}

Source: Production Data from JETRO (2017). The tier structures of Indonesia and Thailand are based on Mizuho Financial Group (2017). The tier structure of Mexico is based on Hoshino (2015) 
Table 8.2 Trade specialization index of Indonesia, Thailand, and Mexico

\begin{tabular}{|c|c|c|c|c|c|c|c|}
\hline \multirow[t]{2}{*}{ HS code } & & \multirow[t]{2}{*}{ rear } & \multirow{2}{*}{$\begin{array}{l}\text { Indonesia } \\
2016\end{array}$} & \multirow{2}{*}{$\begin{array}{l}\text { Thailand } \\
2016\end{array}$} & \multicolumn{3}{|l|}{ Mexico } \\
\hline & & & & & 2012 & 2016 & Change \\
\hline 8703 & $\begin{array}{l}\text { Motor cars and } \\
\text { other mother } \\
\text { vehicles designed to } \\
\text { transport of persons }\end{array}$ & & 0.37 & 0.85 & 0.58 & 0.52 & -0.07 \\
\hline 8708 & $\begin{array}{l}\text { Parts \& access for } \\
\text { motor vehicles }\end{array}$ & & -0.13 & 0.08 & -0.04 & 0.07 & 0.11 \\
\hline 870810 & Bumpers & & -0.43 & 0.43 & -0.21 & -0.10 & 0.11 \\
\hline 870821 & Safety seat belts & & -0.09 & 0.88 & 0.76 & 0.83 & 0.08 \\
\hline 870829 & $\begin{array}{l}\text { Vehicles, parts and } \\
\text { accessories of } \\
\text { bodies, other than } \\
\text { safety seat belts }\end{array}$ & & -0.05 & 0.22 & -0.02 & 0.08 & 0.10 \\
\hline 870830 & $\begin{array}{l}\text { Brakes and } \\
\text { servo-brakes }\end{array}$ & & -0.45 & 0.21 & -0.08 & 0.09 & 0.18 \\
\hline 870840 & Gear boxes & & 0.14 & -0.50 & -0.45 & -0.23 & 0.22 \\
\hline 870850 & $\begin{array}{l}\text { Drive-axels with } \\
\text { differential }\end{array}$ & & -0.39 & -0.07 & 0.11 & 0.31 & 0.20 \\
\hline 870870 & Road wheels & & 0.64 & 0.27 & 0.00 & 0.20 & 0.20 \\
\hline 870880 & Suspension systems & & -0.39 & 0.18 & -0.17 & 0.03 & 0.20 \\
\hline 870891 & Radiators & & 0.34 & 0.32 & -0.10 & -0.00 & 0.10 \\
\hline 870892 & $\begin{array}{l}\text { Mufflers and exhaust } \\
\text { pipes }\end{array}$ & & -0.57 & 0.10 & -0.42 & -0.30 & 0.12 \\
\hline 870893 & Clutches & & -0.08 & 0.07 & -0.50 & -0.44 & 0.06 \\
\hline 870894 & $\begin{array}{l}\text { Steering wheels, } \\
\text { steering columns, } \\
\text { and steering boxes }\end{array}$ & & -0.81 & 0.33 & 0.03 & 0.10 & 0.07 \\
\hline 870895 & $\begin{array}{l}\text { Safety airbags with } \\
\text { inflater system }\end{array}$ & & -0.76 & 0.32 & 0.24 & 0.28 & 0.04 \\
\hline 39 & Plastics and articles & & -0.51 & 0.17 & -0.45 & -0.45 & -0.00 \\
\hline 40 & Rubber and articles & & 0.54 & 0.69 & -0.45 & -0.42 & 0.03 \\
\hline 73 & Iron or steel articles & & -0.27 & -0.23 & -0.23 & -0.24 & -0.01 \\
\hline 76 & $\begin{array}{l}\text { Aluminum and } \\
\text { articles }\end{array}$ & & -0.56 & -0.37 & -0.62 & -0.44 & 0.18 \\
\hline
\end{tabular}

Source: Author created the table using the United Nations Commodity Trade Statistics Database (UN Comtrade)

Note: Trade specialization index is derived as (Export - Import) / (Export + Import) 
same time, the Mexican trade specialization index for raw materials such as plastics, rubber, iron, and aluminum remains negative.

Thus, we can assume that Mexico has become a hub for vehicle production and automotive parts from the number of car makers and, Tier- 1 suppliers located there; however, the presence of domestic Tier-2 firms is still small and a large percentage of parts are supplied from abroad. Using the framework of Taglioni and Winkler (2016), Mexico has already achieved the first step of attracting foreign investors in the automotive sector and this can be the starting point for expanding and strengthening GVC participation.

\section{Hypothesis and Methodologies}

\subsection{Hypothesis}

In this study, the following hypothesis is tested: Kaizen has a positive impact on Tier-2 firms for upgrading in the GVC stages and then on business expansion. In this chapter, we define Kaizen as including not only $5 \mathrm{~S}$ but also several tools from the Toyota Production System (TPS) such as Just in Time and Single Minutes Exchange of Die (SMED), which focus on eliminating any kind of inefficiency in production.

The theory of change in the hypothesis is illustrated in Fig. 8.4. First, if properly implemented (STEP 1), Kaizen can bring about benefits for Tier- $2 \mathrm{~s}$ in terms of quality and productivity (STEP 2). For example, if abnormal conditions in the production space are visualized through $5 \mathrm{~S}$, the production of defective products may be avoided. If mold changing time is reduced, operators can improve productivity. Second, improvement in quality and productivity of Tier- 2 suppliers can trigger improvement in their QCD evaluations by Tier-1 buyers (STEP 3). For example, if the defect/product ratio is reduced by Tier-2 suppliers, Tier-1 buyers may improve their evaluations related to quality. Also, if the production of defective products is reduced in-factory, this can lower production costs. This may be reflected in price quotations and may have positive impact on cost evaluations by Tier- 1 firms. Also, if the changing time for mold is reduced, this will enable firms to produce products with minimum stoppage times of machines. This flexibility may improve delivery times to Tier- 1 buyers. All changes in quality and productivity can thus have positive impacts on the evaluation of QCD by Tier-1 firms. 


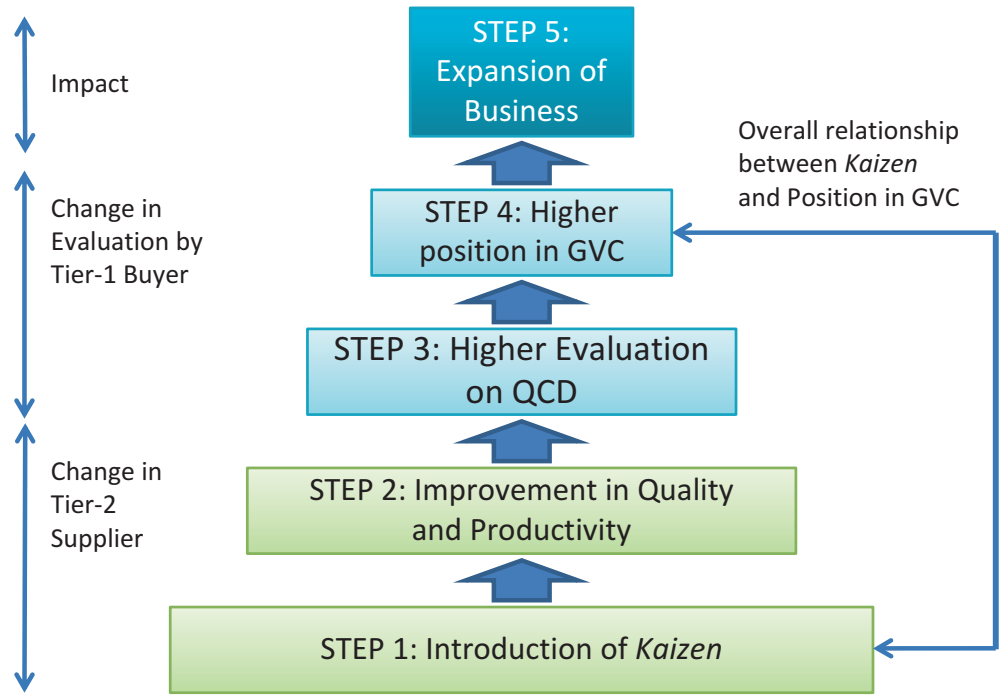

Fig. 8.4 The impact from Kaizen on GVC position and business. (Source: Author)

Third, if Tier- 1 buyers can improve their evaluation of Tier-2 suppliers using QCD, they may feel more comfortable about relying on the supply of parts by Tier- 2 suppliers and this can improve their evaluation of Tier- 2 suppliers in the GVC (STEP 4). Fourth, if Tier-1 firms recognize a Tier-2 supplier as more important and if their position in the GVC is higher, business between them may be expanded. This may also have positive impacts on other Tier-1 buyers when sourcing parts within the automotive industry (STEP 5).

\subsection{Methodology}

This study analyzed flows of impact (Fig. 8.4) using information from both Tier-2 firms and Tier-1 firms. Changes in Tier-1 firm evaluations of GVC position before and after Kaizen were used to identify the overall relationship between intervention using Kaizen and position in the GVC (STEPS 1 and 4).

The analysis of step-by-step impact was carried out as follows: first, improvements in quality and productivity as measured by defective product 
ratios and reductions in mold changing times were analyzed (STEPS 1 and $2)$; second, improvements in quality and productivity were compared with the Tier-1 firm evaluations of QCD (STEP 3); third, Tier-1 firm evaluations of Tier-2 firm QCD were compared with their evaluation of the same firm's position among their suppliers to check whether QCD evaluations influence supplier selection (STEP 4); and finally, expansion of business volume was compared with improvements in GVC position (STEP 5) to check the relevance of Tier-2 focusing on GVC stages to enhance business.

\section{Outline of the Data}

\subsection{Data Sources}

In January 2018, the author obtained data through semi-structured interviews with 15 Mexican Tier-2 firms and 5 Tier-1 firms located in Queretaro State, Guanajuato State, and nearby states. The author also visited factories if possible. The Tier-2 firms were those that JICA has supported in their capacity building efforts and in the introduction of Kaizen. Tier-1 firms are the Japanese FDI firms that buy the products of the Tier- 2 firms (partner Tier-1s). However, as the Tier-1 firms were Japanese FDI only, there is the possibility of selection bias in the results.

Tier-2 firms provided information relating to total sales volume, sales volume for the automotive business, sales volume for major clients, defective product ratios in-factory as well as at-customer, time required for changing molds, and so on. Tier-1s provided an evaluation of their suppliers (Tier-2s) on quality, cost, delivery, overall QCD, and position in the GVC.

\subsection{Outline and Intention of the JICA-Supported Project}

Based on a request from the Government of Mexico, JICA supported a project for automotive supply chain development from 2012 to 2015 . Under this project, JICA collaborated with the state governments of Guanajuato, Queretaro, and Nuevo Leon, as well as with ProMéxico, which is a government agency for promoting trade and investment, in strengthening the supply chains between Japanese Tier- 1 firms and domestic Tier-2 firms.

One of the major components of that project was the capacity development of Tier-2 firms in the field of Kaizen. JICA supported 27 Tier-2 
firms in collaboration with 7 Tier-1 firms by assigning Kaizen experts with experience in the automotive industry, conducting diagnoses of each firm, setting improvement targets in collaboration with buyer Tier-ls, and supporting the implementation of activities for one year. Typical topics were $5 \mathrm{~S}$, reduction of defective product ratios, improvements in job throughput per hour, reduction in mold changing times, reductions in down time, and reduction in inventory.

\section{Findings ANd ANALYsis}

In this study, the relationships between Kaizen and improvement in quality and productivity and positioning in GVC were analyzed. Due to the constraint of survey time, this study covered only Tier-2 firms in the states of Guanajuato and Queretaro.

\subsection{The Overall Relationship Between Kaizen and Position in the GVC}

Under this project, Kaizen activities in the field of productivity and quality by Tier- 2 firms were carried out, along with setting goals in collaboration with Tier-1. The results of the evaluation for each Tier- 2 firm before and after intervention are shown in Fig. 8.5. Of 17 Tier-2 firms that received feedback from their buyers (Tier-1), 8 (47 percent) improved their position (above the line), 5 (29 percent) maintained their position (on the line), and 4 (24 percent) dropped position (below the line). Regarding those firms that dropped position, two had stopped being a supplier due to their high costs and their partner Tier-1 firm's policy of reducing supplier numbers. One stopped being a partner supplier to major suppliers due to trouble with internal management. The remaining firm was evaluated as a major supplier, received higher orders, and constructed a new factory, but their partner Tier-1 degraded evaluations temporarily while settling down the factory. The medium rating before Kaizen was regular supplier (Stage 3 ) and the medium rating after Kaizen was major supplier (Stage 4). However, the information received was only for the treated group and information on changes in positioning in the GVC of the control group or the overall Mexican automotive parts industry could not be obtained. The absence of a control group also affects our ability to infer causality. According to the Tier-1 firms, the number of Tier- 2 suppliers supported under the project remained unchanged or was reduced. This 


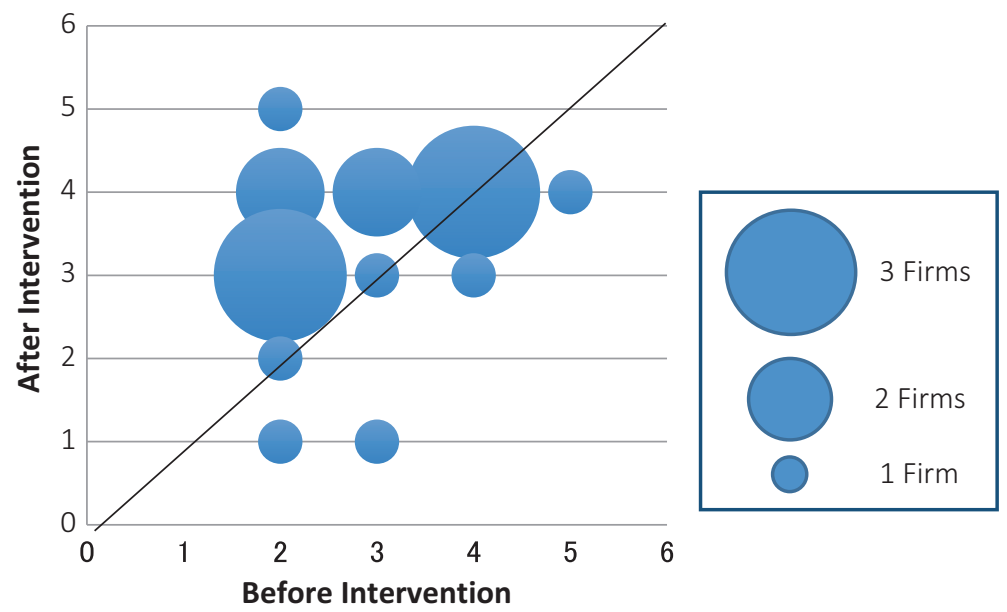

(For both axes; 1: Non Supplier, 2: Periodic/Back up Supplier, 3: Regular Supplier, 4: Major Supplier, 5: Partner Supplier, 6: Global Partner Supplier)

Fig. 8.5 Changes in position in the GVC before and after Kaizen. (Source: Author)

suggests that the relative position of Tier-2 suppliers who improved position in the GVC outperformed other Tier-2 suppliers. To conclude, among those firms that implemented Kaizen during the study period, 76 percent improved or maintained their position in the GVC in comparison to the other Tier- 2 suppliers to the same Tier- 1 buyer.

\subsection{STEPS 1 and 2: Impact of Kaizen on Quality and Productivity}

This section summarizes the information related to quality and productivity before and after intervention using Kaizen.

\subsubsection{Quality}

For quality, a core requirement of Tier- 1 firms is supply of the products that satisfy the specifications defined in the contract between Tier- 1 and Tier-2 firms. This requirement can be interpreted as reduction of the defective product ratio. Accordingly, among the several topics chosen for Kaizen in the JICA project, reduction in defective products was one of the major issues. 
In our survey information on defect rates at the customer level before and after Kaizen intervention and on the evaluation of Tier-2s from the quality viewpoint was collected. In the automotive industry the defect rate is expressed as the number of defective parts per million (PPM). After intervention, the defect rate was reduced substantially. Of the 15 firms that gave information, 10 reduced their defect rate by more than 40 percent or it stayed negligible (0 5 PPM) and 12 firms reduced their rates to less than 100 PPM.

There are no data on the average number of defect PPM in the Mexican auto parts industry, but 100 PPM is lower than the average number of PPM based on JETRO's database on domestic automotive parts makers in Mexico; thus we can suggest that Kaizen has had a positive impact on quality.

\subsubsection{Productivity}

In terms of productivity Kaizen activities were carried out in the areas of reduction of mold changing times, reduction of waiting times for production, inventory reduction, and reduction of defects in-factory. The first two items improve output through higher operation ratios, while the latter reduce inputs related to unused output.

Of the 17 Tier- 2 firms supported by the project, 10 tackled reductions in mold changing time. The average reduction rate was about 54 percent and 6 out of 10 firms reduced this more than 50 percent. In the automotive industry, where around 30,000 parts are used in a vehicle and where assembly of each model is carefully controlled to minimize stock, parts makers are required to adjust production volumes of individual parts every week or so. This creates frequent changes of mold, and each change consumes hours by stopping production machines. This situation negatively affects productivity. The JICA project introduced a method to tackle this issue. It starts with an analysis of the mold changing process, eliminating unnecessary steps, shifting processes requiring stoppage of the machines to processes without stoppage, and improving efficiency in individual steps. This method has been very important in the plastic injection industry, which uses various types of molds and has achieved positive impacts as explained earlier.

Also, of the 17 firms supported by the project, the reduction in the defect rate in-factory by the 13 firms that commented was 54 percent on average, and 9 firms achieved more than 50 percent. To the best of our knowledge, there are no data on productivity improvement in the auto parts industry, so our data could not be compared with an industry average. 


\subsection{STEP 3: Impact of Quality and Productivity on Tier-1 Firms' Evaluation on QCD}

In this section, the relationship between improvements in quality and productivity and Tier- 1 firm evaluations of Tier- 2 firms on quality and cost is discussed. The purpose was to check whether improvements have a positive impact on buyer's perception. Tier- 1 evaluations were classified from unacceptable (level 1) to satisfactory (level 4). Indicators related to delivery were not captured in this project so the relationship between achievement in delivery and evaluation from Tier- 1 firms is not analyzed here.

\subsubsection{Quality}

The relationship between the defect rate after Kaizen intervention and the evaluation of quality is plotted in Fig. 8.6. Of 15 Tier- 2 firms, 12 reduced the defect rate to the customer to less than 100 PPM. Several firms recorded zero or one-digit defects per million products. The firms with less than 100 PPM were evaluated as at either a satisfactory level of quality

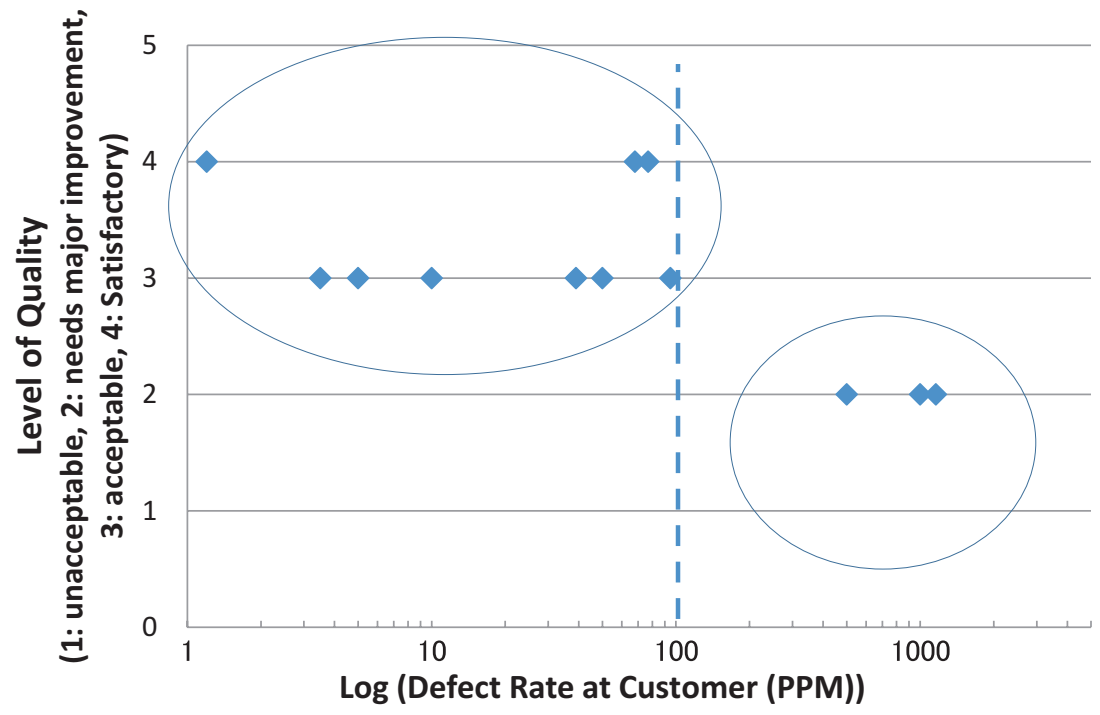

Fig. 8.6 Defect rates and Tier-1 firm evaluations of quality. Note: Four firms are plotted in the upper-left quadrant (negligible PPM and level 4 of quality). (Source: Author) 
or an acceptable level of quality by the Tier- 1 firms that provided feedback (circle upper left). In the three firms that recorded more than 100 PPM, this was evaluated as trouble in quality control (circle lower right).

In Fig. 8.6, plots are concentrated at upper left and lower right, and the defect rate between 100 PPM and 500 PPM is a dividing ridge between acceptable-level quality (level 3 ) and trouble-making quality (level 2). This relationship suggests that improvement in the quality of products measured as reductions in defect rates has a positive impact on the evaluation of quality by buyers. This idea coincides with the Tier- 1 interview results in that they would like their suppliers to reduce defect rates to less than 100 PPM, and preferably down to single digits.

\subsubsection{Cost}

The relationship between productivity and Tier-1 firm evaluations of cost has several intermediary factors. Productivity improvement can have positive impacts on production cost reduction when other factors such as raw materials are kept unchanged. For example, if a company produces a defective product, this will require additional material costs, additional labor, opportunity costs of machine operation, and additional costs for storage. If the cost for setting up a mechanism to reduce the number of defective products is lower than the cost related to defect product, quality control should certainly reduce the total cost of production.

Then, Tier-2 firms will decide how much to quote. They might reflect the entire reduction or part of the reduction of production costs in a quotation. And finally, buyers (Tier-1 firms) will evaluate the price from their own view point. In the automotive sector, it is common practice to have a project life of around five years and car makers request suppliers to achieve reductions in price by 3 percent or so annually. This rate becomes a baseline for negotiation. The second and third steps are negotiation processes, and they are affected by competition. If Tier- 2 firms have several buyers, they might be reluctant to reduce prices substantially. And if Tier-1 firms have several suppliers for a product, they might request a larger reduction.

In this survey, information related to production cost and quotation price could not be captured, but there were two findings. One was expansion of productivity improvement and the other was the Tier-l firm evaluations from a cost point of view. There was no direct relationship observed between defect rate in-factory or reduction in mold changing times and Tier-l firms' evaluation of costs. 
Tier-2 firm interviews showed that all were expanding Kaizen activities to other production lines beyond that supported under the project, recognizing the benefit from those activities. This result supports the hypothesis that Kaizen has a positive impact on production cost. Regarding the evaluation by Tier-1 firms, 12 Tier- 2 firms were evaluated as satisfactory or acceptable from a cost point of view. This result shows that Tier- 2 suppliers are somehow meeting the demand for cost reduction from Tier- 1 firms. There is no evidence, but one of the major sources of these cost reductions could be productivity improvement. Among the four firms rated lower in cost, three had already actively expanded their clients within the auto parts segment and the electrical industry. For them, there may have been a negotiation factor on prices.

To conclude, a positive relationship between low defect rates and Tier-1 firm evaluations of quality was observed. Regarding the relationship between productivity and Tier- 1 firm evaluations on cost, while a clear and direct relationship was not seen, some information that supports the positive relationship was observed.

\subsection{STEP 4: Relationship Between Evaluation of QCD and Evaluation of Positioning in the GVC}

\subsubsection{QCD and Positions in the GVC}

It is widely understood that QCD is an important criterion for auto parts suppliers. This is understandable because, if Tier-2 suppliers can supply the required amount of high-quality product at competitive prices without delay, buyers can utilize the resulting benefits and in turn supply competitive products to car makers. Thus, buyers should be happy to contract those suppliers. To check this viewpoint, Tier- 1 firms were asked to rate their suppliers in terms of QCD as well as their position in the GVC. Supplier rating was categorized from Stage 1 (non-supplier) to Stage 6 (global partner), as defined in the Hypothesis section. QCD rating was carried out from level 1 (unacceptable), level 2 (troublesome, needing major improvement), level 3 (acceptable), to level 4 (satisfactory).

The results of the evaluation for each Tier-2 firm are plotted in Fig. 8.7. By introducing a vertical line between QCD levels B \& C and a horizontal line between GVC levels C \& D, 11 firms are in the first quadrant where both QCD and GVC are high, 3 firms are in the third quadrant where both QCD and GVC are low, and 2 firms are in the second quadrant 


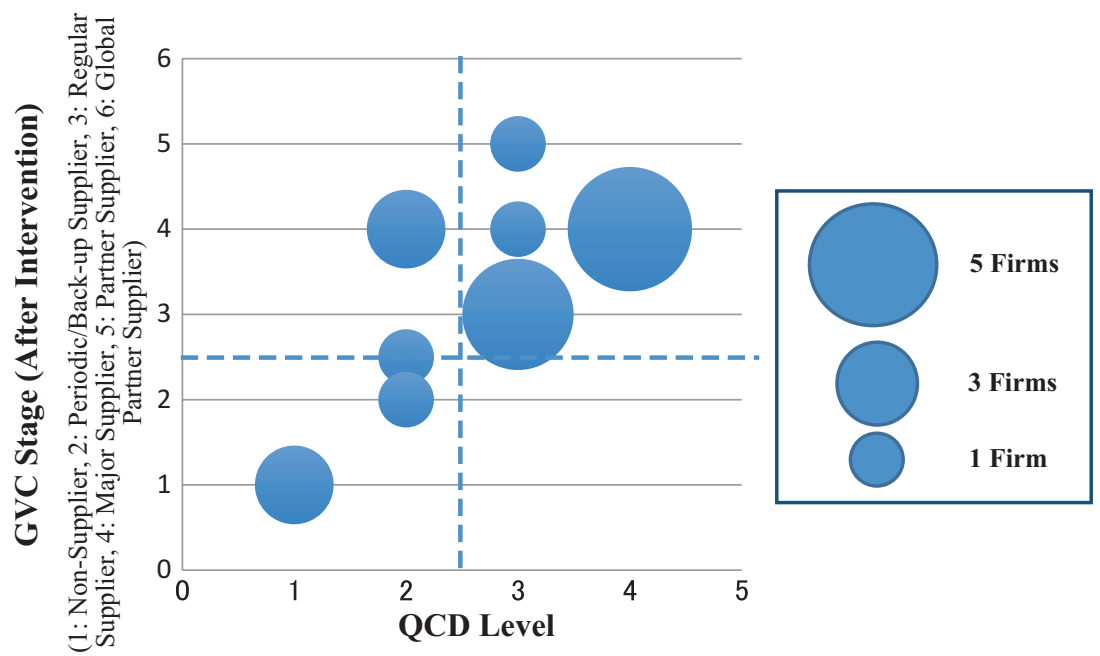

1: Unacceptable, 2: Trouble Making, 3: Acceptable, 4: Satisfactory

Fig. 8.7 Tier-1 firms' evaluation on QCD and position in GVC. (Source: Author)

where QCD is low and GVC is high. One firm is at the border between the second and third quadrants.

Regarding the two firms in the second quadrant, it became clear through the interviews that Tier-ls view the problem of QCD as a somewhat temporary situation for two firms. One company was a major supplier in the past and recently has been facing problems of quality control after shifting to a new factory. Tier- 1 companies were observing this situation as temporary problem that could be managed. In another case, the Tier- 2 was a level 5 (partner supplier) in the past and was regarded as one of the best suppliers in the segment. However, there was a change in company management, and a degradation in cash flow took place when the company was damaged by fraud. It is currently having trouble with product delivery. Nevertheless, the Tier- 1 has some trust in the supplier from their relationship in the past and is hoping to bring the firm back to its original quality level.

Considering the exceptionality of the two firms in the second quadrant, we can observe a positive relationship between QCD level and position in the GVC. Also, we see that it is necessary to achieve QCD 
level 3 (acceptable) or higher to become a regular supplier or to be placed higher in the GVC.

\subsubsection{The Road to Partner Supplier/Role of Support for Tier-2 Firms}

An extended question in the previous section was whether it is possible to be a partner supplier if Tier-2 firms achieve higher ratings in QCD. The answer is "we are not sure," or "not necessarily." As shown in Fig. 8.7, only one firm had a position in the GVC at partner level (level 5). Through an interview with a partner Tier- 1 firm, the history of the Tier- 2 firm that wished to become a partner supplier became clear. At the beginning, the Tier-1 firm nominated the Tier-2 firm for Kaizen intervention because the supplier was facing several issues in QCD. Subsequently the Tier-2 firm introduced $5 \mathrm{~S}$, increased production per hour, reduced time for changing molds, and achieved the goal set by the Tier- 1 firm. The Tier-1 firm found the output to be satisfactory and highly appreciated the commitment of the company to improvement. Subsequently, the Tier- 1 firm considered this Tier- 2 firm to have potential to be a partner firm and provided handson support for it to acquire the capacity to conduct the maintenance of molds and become a partner firm in the new model.

Figure 8.7 also shows that among the eight firms that improved their position in the GVC, all were either regular suppliers (Stage 3 ) or back-up/ periodic suppliers (Stage 2) to higher positions, but none of them were major suppliers (Stage 4). This shows that even if intervention from outside facilitates improvement in the QCD capabilities of firms, it will be effective at relatively lower positions in the GVC, but it is critical to have guidance or commitment from buyers to improve to partner supplier (level 5).

\subsection{STEP 5: Improvement in GVC and Expansion of Business Volume}

The annual growth rates of sales for partner Tier-1 firms under the project as well as the annual growth rate for the auto parts segment were analyzed. Table 8.3 shows the distribution of annual growth rates. Among the growth rate from 0 to 20 percent, a division is inserted at 6 percent, ${ }^{4}$ which was the average growth rate of auto parts in the target region. Linear approximation equations were also prepared for annual growth rate against changes in position in the GVC. If the position moved from a back-up supplier (Stage 2) to a major supplier (Stage 4), the change is recorded as two. Positive relationships between position in GVC and 
Table 8.3 Annual growth rate of sales

\begin{tabular}{|c|c|c|c|c|}
\hline & \multicolumn{2}{|c|}{$\begin{array}{l}\text { Annual growth rate of sales for } \\
\text { partner Tier-1 firms }\end{array}$} & \multicolumn{2}{|c|}{$\begin{array}{l}\text { Annual growth rate of sales for auto } \\
\text { parts segment }\end{array}$} \\
\hline & Number of Tier-2 firms & $\begin{array}{l}\text { Ratio } \\
(\%)\end{array}$ & Number of Tier-2 firms & $\begin{array}{l}\text { Ratio } \\
(\%)\end{array}$ \\
\hline More than $20 \%$ & 4 & 33.3 & 10 & 71.4 \\
\hline More than $0 \%$ & 5 & 41.7 & 4 & 28.6 \\
\hline More than $6 \%$ & 5 & 41.7 & 2 & 14.3 \\
\hline More than $0 \%$ & 0 & 0.0 & 2 & 14.3 \\
\hline $\begin{array}{l}\text { More than } \\
-20 \%\end{array}$ & 2 & 16.7 & 0 & 0.0 \\
\hline $\begin{array}{l}\text { No business } \\
(-100 \%)\end{array}$ & 1 & 8.3 & 0 & 0.0 \\
\hline Total & 12 & 100.0 & 14 & 100.0 \\
\hline \multicolumn{5}{|c|}{ Linear approximation equation $(\Upsilon=a X+b)$} \\
\hline$a$ & -0.9123 & & 0.2522 & \\
\hline$B$ & 0.324 & & 0.0066 & \\
\hline$R$ square & 0.4656 & & 0.0013 & \\
\hline
\end{tabular}

Source: Author

growth of sales for partner Tier-1 firms were observed and a 32 percent increase in sales can be expected for an increase of GVC position by one point. However, a relationship between positions in the GVC and sales volumes was not observed.

Based on the above we can derive two results. One is that improvement in GVC position is positively correlated with business expansion with partner Tier-1 firms. The other is a diversification effect that is exactly what Tier-2 firms are trying to achieve to avoid volatility in business. In this study, out of 15 firms, 10 successfully acquired one to four new Tier- 1 clients.

\section{Conclusions and Policy Implications}

\subsection{Conclusions}

In this study, the relationships between Kaizen and improvements in quality and productivity and positioning in the GVC were analyzed. Seventeen Tier-2 firms were interviewed and therefore a rigorous statistical analysis could not be carried out, but some findings were derived. 
First, the positive impact of Kaizen for improving and maintaining position in the GVC was observed in comparison with other Tier- 2 suppliers for the same Tier-1 firms. Second, the introduction of Kaizen had a positive impact on quality and productivity (STEPS 1 and 2). Indicators of the defective product rates at the customer level were checked for quality, and indicators of mold changing times and the defect product rates infactory were checked from the productivity point of view.

Third, any positive impacts of improvement in quality and productivity on Tier-1 firm evaluations of Tier-2 firms were analyzed (STEP 3). A positive relationship between improvement of quality in terms of defective products at customer and Tier-1 firm evaluations of quality was observed. However, a clear and direct relationship was not observed between productivity and Tier- 1 firm evaluations of cost. Nevertheless, some information that supports positive relationships was observed.

Fourth, a positive relationship between Tier-1 firm evaluation of QCD levels and their evaluation of GVC position was observed (STEP 4). If a Tier-2 firm is targeting to be a major supplier, it should achieve an acceptable level 3 QCD rating by Tier-1 firms. It was also noted that becoming a partner supplier (Stage 5) requires more than QCD and should include support from Tier-1 firms.

Fifth, a positive relationship between Tier-1 firm evaluations of Tier-2 firm positions in the GVC and business volume between the two was observed (STEP 5); however, a relationship between Tier-1 firm evaluations of Tier- 2 firm positions and their total sales in the auto parts segment was not observed. The major reason for this could be the diversification effort by the Tier- 2 firms. It is also observed that 14 out of the 15 firms with data available expanded sales more than the industry average of 6 percent.

\subsection{Policy Implications}

The major policy implication of this study is that the introduction of Kaizen can facilitate promotion in position in the automotive industry GVC, and it should be widely recommended to Tier-2 suppliers to do this. As shown earlier, Tier-2 firms expanded Kaizen activities beyond the production line supported under the project and achieved business expansion higher than the industry average. These results show that the supported Tier-2 firms achieved major internal transformation for production management capabilities as well as competitiveness in the domestic market. 
Second, due to the small sample size concentrating on Japanese Tier-1 firms and the absence of a control group, our ability to infer causality was negatively affected. Further studies should analyze the validity of these conclusions. Also, the relationship between improvements in quality and productivity (STEP 2) and Tier-1 firm evaluations of QCD should be further explored. For example, to explain the relationship between productivity and cost, other intermediary data such as sales price or profit ratios would be useful. The interviews with Tier- 1 firms showed that they evaluate suppliers at the time of trial orders and in periodic reviews of ongoing business. They often reward superior suppliers using these data. Analysis of those evaluations might suggest additional strategies for improving position in the GVC.

Third, Kaizen itself may be difficult to implement in moving Tier-2 firms up to partner supplier level (Stage 5), so it may be better to focus on Tier-2 firms as either back-up/periodic suppliers (Stage 2) or regular suppliers (Stage 3) when providing technical support. For Tier-2 firms to become partner suppliers, additional features such as R\&D capability or a strong relationship with Tier-1 firms might be necessary.

Finally, it is important to have collaboration with Tier-1 firms in implementing Kaizen and setting targets. A target of 100 PPM has been derived from the quality point of view, but it may be better to identify the requirements for improving Tier- 1 firm evaluations on quality, cost, and delivery as well as position in the GVC among competitors through collaboration with Tier-1 firms.

\section{Notes}

1. https://www.nissan-global.com/EN/DOCUMENT/PDF/SR/Renault_ Nissan_Purchasing_Way_English.pdf.

2. http://world.honda.com/sustainability/report/pdf/2015/Honda-SR2015-en-087.pdf.

3. https://www.toyota-industries.com/company/procurement/policy/ index.html.

4. The average growth rate of the industry is based on the interviews of the automotive cluster in Queretaro State.

\section{REFERENCES}

Blalock, Garrick, and Paul J. Gertler. 2008. Welfare Gains from Foreign Direct Investment Through Technology Transfer to Local Suppliers. Journal of International Economics 74 (2): 402-421. 
Cirera, Xavier, and William F. Maloney. 2017. The Innovation Paradox: DevelopingCountry Capabilities and Unrealized Promise of Technological Catch-up. Washington, DC: World Bank.

Cusolito, Ana Paula, Raed Safadi, and Daria Taglioni. 2016. Inclusive Global Value Chains: Policy Options for Small and Medium Enterprises and Low-Income Countries, Directions in Development. Washington, DC: World Bank.

Görg, Holger, and David Greenaway. 2004. Much Ado About Nothing? Do Domestic Firms Really Benefit from Foreign Direct Investment? The World Bank Research Observer 19 (2): 171-197.

Gorodnichenko, Yuriy, Jan Svejnar, and Katherine Terrell. 2014. When Does FDI Have Positive Spillovers? Evidence from 17 Transition Market Economies. Journal of Comparative Economics 42 (4): 954-969.

Guzman-Anaya, Leo. 2013. Inter-Industry Productivity Spillovers from Japanese and US FDI in Mexico's Manufacturing Sector. Technology and Investment 4 (4): 236-243.

Hoshino, Taeko. 2015. Automotive Supply Chain in Mexico. Tokyo-Is It Possible to Participate for Mexican Firms (in Japanese). Tokyo: JETRO, Institute of Developing Economies (IDE).

Japan External Trade Organization (JETRO). 2017. Trends in the Production and Sales of Automotive Parts in Major Countries in 2016. Tokyo: JETRO.

- 2018. Auto Parts Industry in Mexico Still Has Large Opportunities for Expansion of Business from Japan (in Japanese). Area Report. Tokyo: JETRO. Japan International Cooperation Agency (JICA). Forthcoming. Final Report for Project for Elaboration of Industrial Promotion Plans Using Value Chain Analysis in the Republic of the Philippines. Tokyo: JICA.

Javorick, Beata Smarzynska. 2004. Does Foreign Direct Investment Increase the Productivity of Domestic Firms? In Search of Spillovers Through Backward Linkages. American Economic Review 94 (3): 605-627.

Kummritz, Victor. 2016. Do Global Value Chains Cause Industrial Development? CTEI Working Papers 01-2016. Geneva: Centre for Trade and Economic Integration, Graduate Institute.

Kummritz, Victor, Daria Taglioni, and Deborah Winker. 2017. Economic Upgradation Through Global Value Chain Participation: Which Policies Increase the Value Added Gains. Policy Research Working Paper 8007. Washington, DC: World Bank.

Mizuho Financial Group. 2017. Mizuho Research \& Analysis 2017 No. 12. Tokyo: Mizuho Financial Group.

Mudambi, Ram. 2008. Location, Control and Innovation in Knowledge-Intensive Industries. Journal of Economic Geography 8 (5): 699-725.

Taglioni, Daria, and Deborah Winkler. 2016. Making Global Value Chains Work for Development. Trade and Development. Washington, DC: World Bank. https://elibrary.worldbank.org/doi/book/10.1596/978-1-4648-0157-0. 
Open Access This chapter is licensed under the terms of the Creative Commons Attribution 4.0 International License (http://creativecommons.org/licenses/ by $/ 4.0 /$ ), which permits use, sharing, adaptation, distribution and reproduction in any medium or format, as long as you give appropriate credit to the original author(s) and the source, provide a link to the Creative Commons licence and indicate if changes were made.

The images or other third party material in this chapter are included in the chapter's Creative Commons licence, unless indicated otherwise in a credit line to the material. If material is not included in the chapter's Creative Commons licence and your intended use is not permitted by statutory regulation or exceeds the permitted use, you will need to obtain permission directly from the copyright holder.

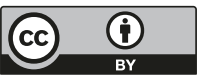

